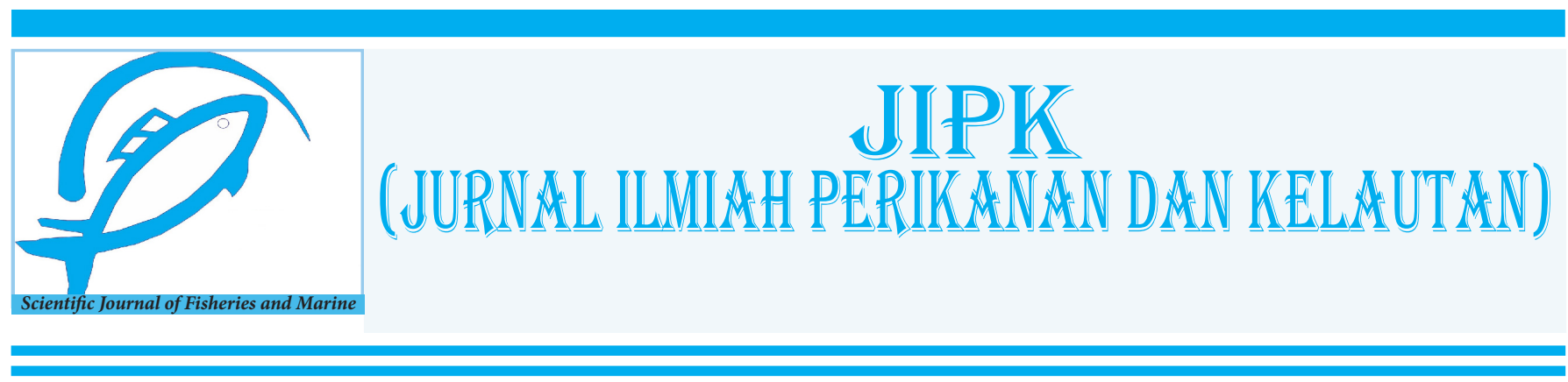

Research Article

\title{
Nano-chitosan Spray as a Preservative and Food Security of Fishery Products in The Middle of the Covid-19 Pandemic
}

\section{Dion Saputra ${ }^{*}$, iD, Ferra Robiatul Ula ${ }^{2}$, Ajeng Budiarahma Nur Fadhila ${ }^{3}$, Yosi Yananda Sijabat ${ }^{4}$, Abista Ahmad Romadoni ${ }^{4}$ and Seto Windarto ${ }^{1}$}

${ }^{1}$ Department of Aquaculture, Faculty of Fisheries and Marine Science, Diponegoro University, Semarang. Indonesia ${ }^{2}$ Department of Fisheries Products Technology, Faculty of Fisheries and Marine Science, Diponegoro University, Semarang. Indonesia

${ }^{3}$ Department of Capture Fisheries, Faculty of Fisheries and Marine Science, Diponegoro University, Semarang. Indonesia ${ }^{4}$ Department of Marine Science, Faculty of Fisheries and Marine Science, Diponegoro University, Semarang. Indonesia

\section{OPEN ACCESS}

\section{$\underline{\text { ARTICLE INFO }}$}

Received: September 20, 2021

Accepted: December 30, 2021

Published: January 03, 2022

*) Corresponding author:

E-mail: dionsaputra@students.

undip.ac.id

Keywords:

Chitosan

Nano-chitosan

Crab Shell

Natural Preservative

Food Security

COVID-19

This is an open access article under the CC BY-NC-SA license (https://creativecommons.org/ licenses/by-nc-sa/4.0/)

\section{Abstract}

The COVID-19 pandemic has impacted the fisheries sector, a decline in exports and fishermen's income caused by the disconnection of the marketing chain due to lockdown implementation in several export destination countries. Fish is a source of protein and as perishable foods, it experiences quality damage due to spoilage, commonly caused by hampered distribution of catches. Natural preservatives are needed to preserve catch so it won't get spoiled and can be accepted by consumers in suitable conditions for consumption. This study aims to evaluate the particle size of nano-chitosan and determine the effectiveness of nano-chitosan spray with different concentrations as a natural preservative in caught fish. This research method begins with making chitosan through 3 stages: demineralization, deproteination, and deacetylation. Chitosan was made into nano-chitosan with various concentrations of $3: 1,4: 1$, and 5:1 using ionic gelation. Nano-chitosan underwent several tests, including PSA, antibacterial activity by disc diffusion, organoleptic, and the effectiveness of preservatives. Antibacterial activity of nanochitosan was able to inhibit Bacillus subtilis at three different concentrations, the potential to inhibit Escherichia coli was optimal at 5:1 treatment. The effectiveness of nano-chitosan preservative bacteria inhibition at three different concentrations proved to be sufficient to be used to extend shelf life and ensure the safety and quality of fishery products. The best concentration of nano-chitosan was $3: 1$ treatment. Nano-chitosan spray from crab shell waste has good antibacterial activity and preservative effectiveness. It could serve as an antibacterial agent and natural preservative for fishery products during the COVID-19 pandemic.

Cite this as: Saputra, D., Ula, F. R., Fadhila, A. B. N., Sijabat, Y. Y., Romadoni, A. A \& Windarto, S. (2022). Nano-chitosan Spray as a Preservative and Food Security of Fishery Products in The Middle of the Covid-19 Pandemic. Jurnal Ilmiah Perikanan dan Kelautan, 14(1):71-82. http://doi.org/10.20473/jipk.v14i1.30121 


\section{Introduction}

The COVID-19 pandemic is a problem that has a significant impact on the fisheries sector, such as a decline in exports and fishermen's income due to the disconnection of the marketing chain of fishery products. The COVID-19 pandemic has caused a decline in fish prices due to several export destination countries (FAO, 2020). The implementation of the lockdown has also caused the spoilage of fish caught by fishermen due to distribution delays. Fish as a food ingredient and a source of protein will spoil and deteriorate in quality. Therefore, it is necessary to preserve fisher's catches so that they are not wasted and can be accepted by consumers in a condition suitable for consumption. In addition, the lockdown has also made it difficult for fishermen to get synthetic preservatives, so a solution to this problem is needed. Therefore, an alternative natural preservative is needed for catching fish that can be produced by themselves without side effects.

Most fisherman have long used synthetic preservatives such as formaldehyde to preserve unsold catches. Usage of formaldehyde to preserve fresh fish is justified due to the technical aspects of being easy to obtain, cheap, and practical (Utama et al., 2021). Formaldehyde is a preservative with hazardous side effects, as stated in the Regulation of the Minister of Health no. 33 of 2012 concerning Food Additives. Formaldehyde is a carcinogenic and mutagenic chemical that can cause cell and tissue damage (Desvita et al., 2020). Besides formaldehyde, people also use borax a lot. Borax is a crystalline compound, white, odorless, and soluble in water (Xie et al., 2017). It is usually used as a preservative, antiseptic, and cockroach repellent, often misused as a food additive to increase the taste and durability of food products (See et al., 2010). Therefore, we need a solution in the form of natural preservatives that can replace synthetic preservatives. Therefore, we need a solution in natural preservatives that can minimize synthetic preservatives such as formaldehyde and borax.

Natural preservatives are preservatives that come from nature and have a lower risk of developing health problems. Natural products have an antioxidant and antibacterial activity that can preserve fisherman catches before the distribution process (Lourenco et al., 2019). Examples of natural preservatives are salt, sugar, and chitosan. Salt can inhibit the growth of microorganisms and reduce water content so that food is more durable (Dwivedi et al., 2017). Sugar can bind water so that it can prevent food spoilage. Chitosan has a role as an inhibitor of the growth of microorganisms (Goy et al., 2009). Chitosan comes from crustacean shells, one of which is crab (Li et al., 2021).

Based on data from Capture Fisheries Statistics 2005-2014, it is stated that the contribution of crabs in a fishery management area of the Republic of Indonesia Indonesia (WPPNRI) 712 covers the waters of the Java Sea by $46.6 \%$. Meanwhile, based on data from KKP statistics of 2019 regarding fishery production, crabs in Central Java province in 2019 reached 8,618.63 tons, therefore the potential for crabs in Central Java waters is very abundant. This shows that the waters of Central Java are one of the largest crab-producing areas in Indonesia. One of the areas included in WPPNRI 712 is Betahwalang, Central Java. Crab (Portunus pelagicus) has a high commercial value, resulting in a significant enough demand for crab catching in the waters of Demak. P. pelagicus is one of Indonesia's leading fishery commodities with crucial economic value for export (Krisnafi et al., 2019). The crab industry produces a lot of solid waste in the form of shell waste. The processing of crabs is directly proportional to the waste produced, so handling efforts are needed to reduce the negative impact on the environment (Bhattacharjee et al., 2019). One small crab produces waste consisting of $57 \%$ shell, $3 \%$ body reject, and $20 \%$ boiled water. One small crab with a weight ranging from 100-350 g has a shell of about 51-177 g. The utilization of crab shell waste can overcome the problem of environmental pollution and waste that continues to increase (Nguyen et al., 2020).

Advanced nanotechnology has accelerated the addressing of food safety concerns in microbial contaminants and improved toxic detection, shelf life, and packaging strategies (Bajpai et al., 2018). Food nanotechnology has the effect of enhancing the bioavailability and nutritional value of food. Nanotechnology can improve food safety, extend shelf life, improve flavor, and detect pathogens/toxins/ pesticides, as well as creating/making functional food (Seabra et al., 2013). Nano-chitosan is one of the products of the nanotechnology process in the form of chitosan nanoparticles. However, all previous studies focused on the manufacture of chitosan and its application as an antibacterial. To our knowledge, very few studies have been conducted on the manufacture of nano-chitosan as a natural preservative for fishery products. Nano-chitosan has a better absorption capacity as an antibacterial and antifungal than chitosan, so it is very suitable for use as a natural preservative (Abdeltwab et al., 2019).

The objectives of the study are to evaluate the particle size of nano-chitosan and determine the effectiveness of nano-chitosan spray with different concentrations as a natural preservative in caught fish. Research results expected are proper antimicrobial, preservative, and food security additive to extend the 
shelf life and ensure fishery product's food safety and security. This research will provide convenience in its application so that fisherman can apply it to their catches so significant and continuous losses do not occur.

\section{Materials and Methods}

This research was conducted from June to August 2021 in Integrated Laboratory Diponegoro University Semarang, Central Java, and the Particle Size Analyzer (PSA) test was carried out at Labqid Jakarta.

\subsection{Sample Preparation}

The material used in this study was crab shells obtained from fisherman from Betahwalang, Demak. The crab shells were cleaned of remaining meat and dirt using water, and then the shells were dried in the sun for approximately two days. The crab shells were mashed using a blender and sieved using a sieve shaker to obtain a powder size of 60 mesh or 250 microns (Supriyantini et al., 2018).

\subsection{Chitosan Production from Crab Shell Waste}

The manufacture of chitosan from crab shells has stages, including demineralization, deproteination, and deacetylation (Supriyantini et al., 2018). Demineralization was carried out by adding $1 \mathrm{~N} \mathrm{HCl}$ solution to the crab shell powder with a ratio of $1: 7(\mathrm{w} / \mathrm{v})$ then stirred using a magnetic stirrer at $200 \mathrm{rpm}$ for $\pm 30 \mathrm{~min}-$ utes until foamy. The mixture was baked at a temperature of $80-90^{\circ} \mathrm{C}$ for 1 hour, then cooled and filtered to obtain a solid, washed with distilled water to a neutral $\mathrm{pH}$. The solid was baked at a temperature of $100^{\circ} \mathrm{C}$ to a constant weight, allowed to cool down to room temperature, and the yield was weighed. Deproteination was done by adding 3.5\% NaOH solution o the demineralized product with a ratio of $1: 10(\mathrm{w} / \mathrm{v})$, stirred using a magnetic stirrer while heated for 1 hour at $70-80^{\circ} \mathrm{C}$, and then the mixture was cooled. The precipitate was filtered and washed with distilled water until the $\mathrm{pH}$ was neutral and at $100^{\circ} \mathrm{C}$ to constant weight. Let it cool down to room temperature and weigh the final weight. The deproteinated product then enters the deacetylation stage, dissolved in $50 \% \mathrm{NaOH}$ at a ratio of $1: 15(\mathrm{w} / \mathrm{v})$ at a temperature of $80-90^{\circ} \mathrm{C}$ while stirred using a magnetic stirrer at $200 \mathrm{rpm}$ for 2 hours and then cooled and filtered. The residue was washed with distilled water until the $\mathrm{pH}$ was neutral and then baked in an oven at $100^{\circ} \mathrm{C}$ to constant weight. Let cool to room temperature and weigh the yield. The result is chitosan.

\subsection{Chitosan Characterization}

Chitosan characterization was carried out by dissolving 0.1 gram of chitosan in $30 \mathrm{ml}$ of $0.1 \mathrm{M} \mathrm{HCl}$, adding 5-6 drops of methyl orange, and titrated using $0.1 \mathrm{M} \mathrm{NaOH}$ solution. The titration process was carried out until the color was orange (acid-base method). According to Triastiningrum and Purnomo (2016), the degree of deacetylation (DDA) is calculated by the following equation.

$D D A(\%)=\frac{(C 1 V 1-C 2 V 2)}{M \times 0,0994} \times 0,016$

Note: $\mathrm{C} 1$ is the concentration of the standard $\mathrm{HCl}$ solution, $\mathrm{V} 1$ is the volume of the standard $\mathrm{HCl}$ solution, $\mathrm{C} 2$ is the concentration of the standard $\mathrm{NaOH}$ solution, $\mathrm{V} 2$ is the volume of the standard $\mathrm{NaOH}$ solution, and $\mathrm{M}$ is the weight of chitosan.

\subsection{Preparation of Nano-chitosan by Ionic Gela- tion}

The manufacture of nano-chitosan was carried out using ionic gelation, by making $0.2 \%$ chitosan solution in acetic acid solution and then adding 1\% NaTPP solution with a ratio of $5: 1,4: 1$, and $3: 1$ with stirring speed of 300, 600, and $900 \mathrm{rpm}$ for 1 hour. Nano-chitosan was obtained in the form of dispersed solids (Arsyi et al., 2018).

\subsection{PSA (Particle Size Analyzer) Test}

The particle size characterization of nano-chitosan was carried out by adding $40 \%(\mathrm{w} / \mathrm{v}) \mathrm{NaOH}$ in a nano-chitosan ratio of $1: 15(\mathrm{w} / \mathrm{v})$ and then heated in a Particle Size Analyzer (PSA) with laser diffraction to determine the particle size distribution (Arsyi et al., 2018).

\subsection{Manufacturing and Application of Nano-chi- tosan Spray}

Nano-chitosan spray was obtained by mixing nano-chitosan powder and acetic acid solvent with a ratio of 3:1 (w/v) in a $100 \mathrm{ml}$ spray container and homogenized. The application of nano-chitosan spray is made by spraying it evenly on the surface of the fish. This is the same as what was done from research by Hamdayanti et al. (2012), where the process of applying natural preservatives in the form of a spray is done by spraying a chitosan solution over the entire surface of the sample using a sprayer. Controls were sprayed with sterile water. 


\subsection{Antibacterial Activity Test with Disc Diffusion Method}

The disc diffusion method was carried out by wetting the disc paper with a solution of nano-chitosan and then placing it on Mueller Hinton Agar which is covered with E. coli and B. subtilis. B. subtilis is a Gram-positive spore-forming bacterium (Lestari et al., 2019) and E. coli is a short-rod Gram-negative bacterium (Bambang et al., 2014), where these types of bacteria are often found in waters and caught fish. Then it was incubated for 24 hours at $37^{\circ} \mathrm{C}$ and dripped with $2 \%$ Amoxilin. Based on research of Prasetiowati et al. (2018), a positive disc diffusion is indicated by the presence of a clear zone around disc paper.

\subsection{Organoleptic Test}

The organoleptic test were carried out on 12 types of fish species that had been sprayed with nano-chitosan in a ratio of $3: 1,4: 1$, and 5:1 as well as control treatment for each fish species. This test employs 25 panelists. Based on research of Syafitri et al. (2016), organoleptic assessment was carried out on eyes, gills, mucus, flesh, texture, and smell by providing a detailed assessment. The data obtained from the results of the organoleptic assessment were analyzed descriptively to determine the level of freshness of the fish. The organoleptic test guidelines are carried out in accordance with the Indonesian National Standard for Fresh Fish (SNI 2729:2013) and fish that are fit for consumption have an organoleptic value of more than 7 .

\subsection{Preservative Effectiveness Test}

A preservative effectiveness test was carried out by measuring the resistance time of fish against bacteria. The measurement started right after spraying the nano-chitosan spray on the fish until its decayed. The long resistance of fish to bacteria shows that nano-chitosan spray acts as a natural preservative. This is the same as what was done from research Cahyaningsih et al. (2021), where the testing of preservative activity was carried out by observing the physical changes of the sample until its optimal storage period (days) to determine the level of resistance of the sample.

\section{Results and Discussion}

COVID-19 has implications for restrictions on movement across countries, which causes food distribution to be hampered. Therefore, the local food supply and the traditional food sector must be revived because they have a role in food availability during the pandemic. One alternative to overcome the lack of food supply can be done by adding natural preservatives (Thulasiraman et al., 2021). The antibacterial activity of chitosan has been highlighted to extend the product's shelf life. Nano-chitosan is a natural material with excellent quality and physicochemical properties. Nano-chitosan has been investigated by several approaches, including physical cross-linking by ionic gelation between chitosan and specific negatively charged macromolecules such as sodium tripolyphosphate. In addition, the coating of chitosan nanoparticles can be used as natural or chemical antimicrobial agents, antioxidants, enzymes, or active substances (Abdeltwab et al., 2019). During the product storage period, nano-chitosan showed higher antimicrobial activity than chitosan because of the larger surface area of nano-chitosan and higher affinity for bacterial cells (Ramezani et al., 2015).

\subsection{Chitosan from Crab Shell Waste}

The manufacture of chitosan in this study was carried out through 3 stages: demineralization, deproteination, and deacetylation of 400 grams of crab shell waste. Demineralization aims to remove minerals contained in the crab shells. Deproteination aims to remove the protein in the crab shell using $\mathrm{NaOH}$ solution. The deproteinized product will enter the deacetylation stage using a $50 \% \mathrm{NaOH}$ solution for 2 hours at a temperature of $80-90^{\circ} \mathrm{C}$. The use of alkaline solutions with high concentrations and high temperatures during the deacetylation process can break the bonds between the acetyl group and the nitrogen atom to turn into an amine group.

Table 1. Results of the Stages Making Process Chitosan

\begin{tabular}{lcc}
\hline Stage & Product Mass (g) & Yield (\%) \\
\hline Demineralization & 254 & 63,5 \\
Deproteination & 184 & 46 \\
Deacetylation & 154 & 38,5 \\
\hline
\end{tabular}

Chitosan is obtained from the final product of deacetylation of crab shells, then made into nano-chitosan. The chitosan yield was obtained by dividing the resulting chitosan with the initial weight of the sample multiplied by $100 \%$. Chitosan yield decreased from initial yield of $100 \%$ to the final yield of $38.5 \%$, this 
JIPK. Volume 14 No 1. April 2022 / Nano-chitosan Spray as a Preservative and Food Security of Fishery Products in

occurred along the increasing concentration of $\mathrm{NaOH}$ solution and the temperature used. The yield of crab shell chitosan was higher than the research conducted by Supriyantini et al. (2018). Based on the research of Supriyantini et al. (2018), the yield of chitosan from crab shells obtained was $36.84 \%$. The total chitosan produced from 400 grams of crab shells is $154 \mathrm{~g}(38.5 \%)$ (Table 1).

\subsection{Chitosan Characterization}

Crab shell chitosan has a deacetylation degree of $96.58 \%(\mathrm{NaOH}$ volume $=24 \mathrm{ml})$.

$$
\begin{gathered}
D D A(\%)=\frac{(C 1 V 1-C 2 V 2)}{M \times 0.0994} \times 0.016 \\
D D A(\%)=\frac{(0.1 \times 30-0.1 \times 24)}{0.1 \times 0.0994} \times 0.016 \\
D D A(\%)=96.58 \%
\end{gathered}
$$

The deacetylation process of crab shell chitosan resulted in a deacetylation degree of $96.58 \%$, which had exceeded the $70 \%$ deacetylation degree to meet the standard of chitosan. Based on the research of Vilar et al. (2016), good chitosan according to quality standards must have a degree of deacetylation of more than $50 \%$.

\subsection{Nano-chitosan with Ionic Gelation}

Nano-chitosan is the application of nanoparticle technology to chitosan. Chitosan from the deacetylation stage of 154 grams will then be made into nano-chitosan using the ionic gelation method. Ionic gelation is a method that is widely used because the process is effective, simple, and can be controlled easily. The ionic gelation mechanism is that chitosan is dissolved in acetic acid then polyanions are added so that nanoparticles will spontaneously form with consistent stirring (Qonitannisa et al., 2020). The polyanion compound used is Natrium Tripolyphosphate (NaTPP) because this compound is not toxic and can interact with chitosan through electrostatic forces to form ionic crosslinks. Nano-chitosan was made with three concentration variations, such as 5:1, 4:1, and 3:1 (Figure 1). The 3:1 concentration of nano-chitosan solution consisted of $300 \mathrm{ml}$ of $0.2 \%$ chitosan solution with $100 \mathrm{ml}$ of $1 \%$ NaTPP. The 4:1 concentration of nano-chitosan solution consisted of $400 \mathrm{ml}$ of $0.2 \%$ chitosan solution with $100 \mathrm{ml}$ of $1 \%$ NaTPP. The $5: 1$ concentration of nano-chitosan solution consisted of $500 \mathrm{ml}$ of $0.2 \%$ chitosan solution with $100 \mathrm{ml}$ of $1 \%$ NaTPP.

\subsection{Particle Size Analyzer (PSA) Test}

The determination of nano-chitosan particle size was carried out using the PSA (Particle Size Analyzer) test because the measurement results were in the form of distribution to determine the overall nano-chitosan particle size (Table 2).

Based on PSA analysis, the results were 943.7 $\mathrm{nm}$ at 3:1 spray nano-chitosan concentration, $626.4 \mathrm{~nm}$ at 4:1 nano-chitosan spray concentration, and $131.6 \mathrm{~nm}$ at 5:1 nano-chitosan spray concentration. Concentrations of nano-chitosan at concentrations of $3: 1,4: 1$, and 5:1 have nanoparticle sizes, where nanoparticles have more than $100 \mathrm{~nm}$. Particle size nano-chitosan from the three concentrations in this study ranged from 130 - $940 \mathrm{~nm}$, so it can be said that the synthesis of chitosan nanoparticles in this study has been successful and will be optimally used in antibacterial tests and other tests. This is under research conducted by Abdeltwab et al. (2019), where the antimicrobial activity of chitosan nanoparticles increases when their size gets smaller. The smaller the nanoparticle size, the larger the surface area and the increased contact with microbes (Guzman et al., 2012).

Table 2. Analysis of Particle Size Analyzer Nano-chitosan Solution

\begin{tabular}{lcc}
\hline Sample & Ratio (w/v) & Particle Size (nm) \\
\hline Nano-chitosan & $3: 01$ & 943,7 \\
Nano-chitosan & $4: 01$ & 626,4 \\
Nano-chitosan & $5: 01$ & 131,6 \\
\hline
\end{tabular}

\subsection{Antibacterial Activity Test with Disc Diffusion Method}

Disc diffusion method in the antibacterial activity test aims to determine the potential of nano-chitosan in inhibiting the growth of E. coli and B. subtilis bacteria. A positive test for antibacterial activity in an extract or compound using disc diffusion marked by a clear or inhibitory zone that appears around the paper disc (Prasetiowati et al., 2018). 
Saputra et al. / JIPK, 14(1):71-82

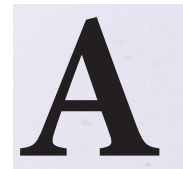

B
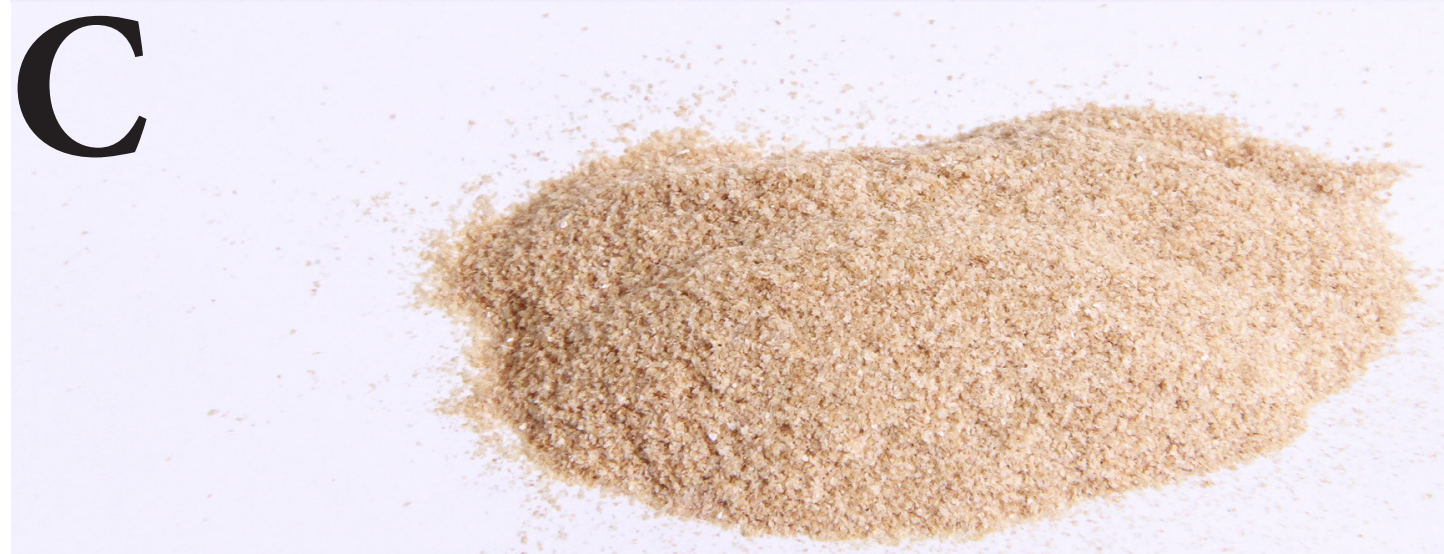

Figure 1. Nano-chitosan powder with concentrations of: (A) 3:1, (B) 4:1 and (C) 5:1 
Table 3. Antibacterial Activity Test Disc Diffusion Method

\begin{tabular}{cccc}
\hline \multirow{2}{*}{ Sample } & \multicolumn{3}{c}{ Parameter } \\
\cline { 2 - 4 } & $\begin{array}{c}\text { Ratio } \\
(\mathbf{w : v )}\end{array}$ & $\begin{array}{c}\text { Clear } \\
\text { Zone } \\
(\mathbf{m m})\end{array}$ & $\begin{array}{c}\text { Types of Pathogenic } \\
\text { Bacteria }\end{array}$ \\
\hline Nano-chitosan & $3: 01$ & 1 & Bacillus subtilis \\
Nano-chitosan & $4: 01$ & 1 & Bacillus subtilis \\
Nano-chitosan & $5: 01$ & 1 & Bacillus subtilis \\
Nano-chitosan & $3: 01$ & 0 & Escherichia coli \\
Nano-chitosan & $4: 01$ & 0 & Escherichia coli \\
Nano-chitosan & $5: 01$ & 0,5 & Escherichia coli \\
\hline
\end{tabular}

Description: w: chitosan, v: NaTTP

Quantitative analysis of the antibacterial properties of crab nano-chitosan has the potential with the presence of an inhibition zone around the test point; as shown in (Table 3), the results of the nano-chitosan activity test were able to inhibit the growth of $B$. subtilis at three different concentrations, while the potential to inhibit the growth of $E$. coli was optimal at a concentration of $5: 1$.

The mechanism of nano-chitosan has potential as an antibacterial as it has a very strong positive charge that can attract negatively charged amino acid molecules that form proteins in microbes. These positive and negative charges interact electrostatically, which causes the membrane to experience a permeable pressure which causes an imbalance in the osmotic pressure inside the cell, which hinders the growth of microbes. Intracellular hydrolysis events also occur in the cell wall which causes the release of cell electrolytes, thus causing the death of a microbial cell (Sarwono, 2010).

This study tested nano-chitosan against $E$. coli and B. subtilis bacteria because these bacteria are amongst the most prevalent in fishery products in the process of fish quality deterioration. B. subtilis bacteria play a role in the decay of meat and protein ingredients, like fish (Sari et al., 2019). Meanwhile, E. coli spreads easily through contaminated water thus contaminating fresh fish (Sumampouw, 2018). If the growth of these bacteria is not stopped, it will cause foodborne diseases that will harm consumers and fisherman.

\subsection{Organoleptic Test}

The organoleptic test utilizes human senses as the main tool in measuring the quality of a product. Organoleptic test parameters on tilapia, mullet, milkfish, mackerel, kipper, and catfish included eyes, gills, mucus, meat, odor, and texture, while organoleptic test parameters on squid, cuttlefish, and shrimp included appearance, smell, and texture. The test results are filled in on the organoleptic assessment sheet of fresh fish based on the Indonesian National Fresh Fish Standard (SNI 2729:2013). The sample in the organoleptic test is suitable for consumption if it has an organoleptic score of at least 7 . The organoleptic analysis data using nano-chitosan spray is presented in the following table.

The organoleptic table on the first day showed that the fish with the nano-chitosan spray had an organoleptic value of more than 7 , so it was suitable for consumption. In contrast, the fish with the control treatment had an organoleptic value below 7 , so it was unsuitable for consumption.

Table 4. Organoleptic Analysis of Fishery Products First Day after Spraying

\begin{tabular}{lcccc}
\hline \multirow{2}{*}{ Species } & \multicolumn{3}{c}{ Nano-chitosan Concentration } \\
\cline { 2 - 5 } & $\mathbf{3 : 0 1}$ & $\mathbf{4 : 0 1}$ & $\mathbf{5 : 0 1}$ & Control \\
\hline $\begin{array}{l}\text { Oreochromis } \\
\text { mossambicus }\end{array}$ & 7,67 & 7,45 & 7,19 & 6,54 \\
$\begin{array}{l}\text { Oreochromis } \\
\text { niloticus }\end{array}$ & 7,67 & 7,45 & 7,19 & 6,54 \\
Mugil cephalus & 7,65 & 7,5 & 7,26 & 6,57 \\
Chanos chanos & 7,65 & 7,5 & 7,26 & 6,57 \\
$\begin{array}{l}\text { Litopenaeus } \\
\text { vannamei }\end{array}$ & 7,68 & 7,53 & 7,36 & 6,53 \\
$\begin{array}{l}\text { Penaeus } \\
\text { merguensis }\end{array}$ & 7,68 & 7,53 & 7,36 & 6,53 \\
$\begin{array}{l}\text { Loligo spp } \\
\text { Sepia spp }\end{array}$ & 7,54 & 7,42 & 7,29 & 6,61 \\
$\begin{array}{l}\text { Rastrelliger } \\
\text { kanagurta }\end{array}$ & 7,54 & 7,42 & 7,29 & 6,61 \\
$\begin{array}{l}\text { Scomberomorus } \\
\text { commerson }\end{array}$ & 7,56 & 7,45 & 7,18 & 6,5 \\
$\begin{array}{l}\text { Scatophagus argus } \\
\text { Clarias gariepinus }\end{array}$ & 7,59 & 7,43 & 7,24 & 6,52 \\
\hline & & 7,44 & 7,16 & 6,45 \\
\hline
\end{tabular}


Table 5. Organoleptic Analysis of Fishery Products Second Day after Spraying

\begin{tabular}{|c|c|c|c|c|}
\hline \multirow[t]{2}{*}{ Species } & \multicolumn{4}{|c|}{$\begin{array}{c}\text { Nano-chitosan Concentration } \\
(\mathrm{w} / \mathrm{v})\end{array}$} \\
\hline & 3:01 & $4: 01$ & 5:01 & Control \\
\hline $\begin{array}{l}\text { Oreochromis } \\
\text { mossambicus }\end{array}$ & 7,64 & 7,42 & 7,16 & 6,28 \\
\hline $\begin{array}{l}\text { Oreochromis } \\
\text { niloticus }\end{array}$ & 7,64 & 7,42 & 7,16 & 6,28 \\
\hline $\begin{array}{l}\text { Mugil } \\
\text { cephalus }\end{array}$ & 7,64 & 6,6 & 6,5 & 5,39 \\
\hline $\begin{array}{l}\text { Chanos } \\
\text { Chanos }\end{array}$ & 7,64 & 6,6 & 6,5 & 5,39 \\
\hline $\begin{array}{l}\text { Litopenaeus } \\
\text { vannamei }\end{array}$ & 7,65 & 7,5 & 6,5 & 5,46 \\
\hline $\begin{array}{l}\text { Penaeus } \\
\text { merguensis }\end{array}$ & 7,65 & 7,5 & 6,5 & 5,46 \\
\hline Loligo spp. & 7,52 & 7,37 & 6,46 & 5,33 \\
\hline Sepia spp. & 7,52 & 7,37 & 6,46 & 5,33 \\
\hline $\begin{array}{l}\text { Rastrelliger } \\
\text { kanagurta }\end{array}$ & 7,64 & 7,48 & 6,5 & 5,39 \\
\hline $\begin{array}{l}\text { Scomberomorus } \\
\text { Commerson }\end{array}$ & 7,54 & 6,23 & 6,45 & 5,33 \\
\hline $\begin{array}{l}\text { Scatophagus } \\
\text { argus }\end{array}$ & 7,54 & 7,4 & 6,44 & 5,36 \\
\hline $\begin{array}{l}\text { Clarias } \\
\text { gariepinus }\end{array}$ & 7,21 & 6,44 & 6,67 & 5,28 \\
\hline
\end{tabular}

The organoleptic table on the second day showed that $O$. niloticus with 3:1 and 4:1 nano-chitosan spray as well as $O$. mossambicus with 5:1 nano-chitosan spray had organoleptic values of more than 7 , so they were suitable for consumption. In contrast, the fish with control and spray treatments of nano-chitosan ratio of $5: 1$ has an organoleptic value below 7 , so it is unsuitable for consumption.

Based on the organoleptic table on the third day, it showed that spraying nano-chitosan with a concentration of 3:1 was able to maintain freshness in particular species, which included $O$. niloticus, O. mossambicus, Litopenaeus vannamei, Penaeus merguensis, Loligo spp, Sepia spp, Rastrelliger kanaguarta, and Scatophagus argus. Spraying nanochitosan with concentrations of $4: 1$ and 5:1 was able to maintain freshness in certain species, including $O$. niloticus and O. mossambicus. Control treatment on organoleptic test showed that all fish were unfit for consumption.

Table 6. Organoleptic Analysis of Fishery Products on the Third Day after Spraying

\begin{tabular}{|c|c|c|c|c|}
\hline \multirow{2}{*}{ Species } & \multicolumn{4}{|c|}{$\begin{array}{l}\text { Nano-chitosan Concentration } \\
(\mathbf{w} / \mathbf{v})\end{array}$} \\
\hline & $3: 01$ & 4:01 & $5: 01$ & Control \\
\hline $\begin{array}{l}\text { Oreochromis mos- } \\
\text { sambicus }\end{array}$ & 7,55 & 7,39 & 7,63 & 5,63 \\
\hline $\begin{array}{l}\text { Oreochromis ni- } \\
\text { loticus }\end{array}$ & 7,55 & 7,39 & 7,63 & 5,63 \\
\hline Mugil cephalus & 6,55 & 6,42 & 6,41 & 3,76 \\
\hline Chanos Chanos & 6,55 & 6,42 & 6,41 & 3,76 \\
\hline $\begin{array}{l}\text { Litopenaeus van- } \\
\text { namei }\end{array}$ & 7,62 & 6,61 & 6,73 & 4,36 \\
\hline $\begin{array}{l}\text { Penaeus merguen- } \\
\text { sis }\end{array}$ & 7,62 & 6,61 & 6,73 & 4,36 \\
\hline Loligo spp. & 7,49 & 6,5 & 6,48 & 4,73 \\
\hline Sepia spp. & 7,49 & 6,5 & 6,48 & 4,73 \\
\hline $\begin{array}{l}\text { Rastrelliger kana- } \\
\text { gurta }\end{array}$ & 7,6 & 6,6 & 6,46 & 4,75 \\
\hline $\begin{array}{l}\text { Scomberomorus } \\
\text { Commerson }\end{array}$ & 6,48 & 6,38 & 6,36 & 3,71 \\
\hline Scatophagus argus & 7,57 & 6,52 & 6,31 & 4,7 \\
\hline Clarias gariepinus & 6,42 & 6,21 & 6,22 & 3,38 \\
\hline
\end{tabular}

The organoleptic table on the fourth day showed that spraying nano-chitosan with a concentration of $3: 1$ was able to maintain the freshness of $L$. vannamei and $P$. merguensis. All fish were unfit for consumption in the control treatment and spraying of nano-chitosan with concentrations of 4:1 and 5:1 in the organoleptic test.

Based on the results of the organoleptic test, it is known that the three concentrations of $3: 1,4: 1$, and 5:1 can maintain fish quality for four days. On L. vannamei and P. merguensis able to last for 5 days. So it can be concluded that the concentration of $3: 1$ is the best in preserving the catch, particularly $L$. vannamei and $P$. merguensis 
JIPK. Volume 14 No 1. April 2022 / Nano-chitosan Spray as a Preservative and Food Security of Fishery Products in

Table 7. Organoleptic Analysis of Fishery Products on the Fourth Day after Spraying

\begin{tabular}{|c|c|c|c|c|}
\hline \multirow{2}{*}{ Species } & \multicolumn{4}{|c|}{$\begin{array}{c}\text { Nano-chitosan Concentration } \\
(\mathrm{w} / \mathrm{v})\end{array}$} \\
\hline & 3:01 & 4:01 & $5: 01$ & Control \\
\hline $\begin{array}{l}\text { Oreochromis } \\
\text { mossambicus }\end{array}$ & 6,68 & 6,52 & 6,28 & 4,25 \\
\hline $\begin{array}{l}\text { Oreochromis } \\
\text { niloticus }\end{array}$ & 6,68 & 6,52 & 6,28 & 4,25 \\
\hline Mugil cephalus & - & - & - & - \\
\hline Chanos Chanos & - & - & - & - \\
\hline $\begin{array}{l}\text { Litopenaeus } \\
\text { vannamei }\end{array}$ & 7,54 & 6,39 & 6,37 & 3,59 \\
\hline $\begin{array}{l}\text { Penaeus } \\
\text { merguensis }\end{array}$ & 7,54 & 6,39 & 6,37 & 3,59 \\
\hline Loligo spp. & 6,57 & 6,42 & 6,45 & 3,41 \\
\hline Sepia spp. & 6,57 & 6,42 & 6,45 & 3,41 \\
\hline $\begin{array}{l}\text { Rastrelliger } \\
\text { kanagurta }\end{array}$ & 6,55 & 6,42 & 6,41 & 3,76 \\
\hline $\begin{array}{l}\text { Scomberomorus } \\
\text { Commerson }\end{array}$ & - & - & - & - \\
\hline $\begin{array}{l}\text { Scatophagus } \\
\text { argus }\end{array}$ & 6,5 & 6,39 & 6,39 & 3,46 \\
\hline $\begin{array}{l}\text { Clarias } \\
\text { gariepinus }\end{array}$ & - & - & - & - \\
\hline
\end{tabular}

Biochemical spoilage of fish occurs with a marked change in $\mathrm{pH}$ due to the autolysis process, so that it will accelerate the decline in fish quality. The decline in the quality of fishery products can affect the flavor and aroma of the fish, which will result in the selling value because the fish is not fit for consumption. According to Nurhayati et al. (2019), the decline in fish quality is influenced by the type, size of fish, bacteria or enzymes, oxidation, the fishing process, the environment, and the way the catch is handled so that it affects the interest and purchasing power of consumers towards the catches of fisherman to be caught for sale.
Table 8. Organoleptic Analysis of Fishery Products on the Fifth Day after Spraying

\begin{tabular}{|c|c|c|c|c|}
\hline \multirow[t]{2}{*}{ Species } & \multicolumn{4}{|c|}{$\begin{array}{c}\text { Nano-chitosan Concentration } \\
(\mathrm{w} / \mathrm{v})\end{array}$} \\
\hline & 3:01 & $4: 01$ & $5: 01$ & Control \\
\hline $\begin{array}{l}\text { Oreochromis } \\
\text { mossambicus }\end{array}$ & - & - & - & - \\
\hline $\begin{array}{l}\text { Oreochromis } \\
\text { niloticus }\end{array}$ & - & - & - & - \\
\hline Mugil cephalus & - & - & - & - \\
\hline Chanos Chanos & - & - & - & - \\
\hline $\begin{array}{l}\text { Litopenaeus } \\
\text { vannamei }\end{array}$ & 6,38 & 6,33 & 6,29 & 3,44 \\
\hline Penaeus merguensis & 6,38 & 6,33 & 6,29 & 3,44 \\
\hline Loligo spp. & - & - & - & - \\
\hline Sepia spp. & - & - & - & - \\
\hline $\begin{array}{l}\text { Rastrelliger } \\
\text { kanagurta }\end{array}$ & - & - & - & - \\
\hline $\begin{array}{l}\text { Scomberomorus } \\
\text { Commerson }\end{array}$ & - & - & - & - \\
\hline Scatophagus argus & - & - & - & - \\
\hline $\begin{array}{l}\text { Clarias } \\
\text { gariepinus }\end{array}$ & - & - & - & - \\
\hline
\end{tabular}

\subsection{Preservative Effectiveness Test}

A preservative effectiveness test is used to determine the ability of preservatives when applied to a fishery product. The test was carried out by calculating the shelf life of the product after spraying nano-chitosan (Table 9).

Based on the effectiveness test results, it is known that the concentrations of 3:1, 4:1, and 5:1 extend the shelf life of fishery products because they have quite effective antimicrobial content. The best concentration of nano-chitosan spray is $3: 1$, with the ability to preserve shrimp for up to 5 days. Spray nano-chi- 
tosan with a concentration of 3:1 is effective for shrimp preservation because it has a smaller particle size to be well absorbed on the surface of the shrimp. This is in accordance with research conducted by Abdeltwab et al. (2020), where the antimicrobial activity and permeability of chitosan nanoparticles increases when their size gets smaller.

Table 9. Preservative Effectiveness Test Analysis

\begin{tabular}{|c|c|c|c|c|}
\hline \multirow{2}{*}{ Species } & \multicolumn{4}{|c|}{$\begin{array}{c}\text { Nano-chitosan Concentration } \\
\text { (Days) }\end{array}$} \\
\hline & 3:01 & 4:01 & $5: 01$ & Control \\
\hline $\begin{array}{l}\text { Oreochromis } \\
\text { mossambicus }\end{array}$ & 4 & 3 & 2 & 1 \\
\hline $\begin{array}{l}\text { Oreochromis } \\
\text { niloticus }\end{array}$ & 4 & 3 & 2 & 1 \\
\hline Mugil cephalus & 2 & 2 & 2 & 1 \\
\hline Chanos Chanos & 3 & 2 & 2 & 1 \\
\hline $\begin{array}{l}\text { Litopenaeus } \\
\text { vannamei }\end{array}$ & 5 & 4 & 2 & 1 \\
\hline Penaeus merguensis & 5 & 4 & 2 & 1 \\
\hline Loligo spp. & 4 & 3 & 2 & 1 \\
\hline Sepia spp. & 4 & 3 & 2 & 1 \\
\hline $\begin{array}{l}\text { Rastrelliger } \\
\text { kanagurta }\end{array}$ & 4 & 3 & 2 & 1 \\
\hline $\begin{array}{l}\text { Scomberomorus } \\
\text { Commerson }\end{array}$ & 3 & 2 & 2 & 1 \\
\hline Scatophagus argus & 4 & 3 & 2 & 1 \\
\hline Clarias gariepinus & 3 & 2 & 2 & 1 \\
\hline
\end{tabular}

\section{Conclusion}

The size of the nano-chitosan particles is able to affect the effectiveness of the nano-chitosan spray produced, where the smaller the nanoparticles in the nano-chitosan, the better the effectiveness of the nano-chitosan spray. The best small crab shell nano-chitosan particle size is $943.7 \mathrm{~nm}$ obtained from nano-chitosan with a ratio of 3:1. Spray nano-chitosan from crab shells was effective in the preservation process of $L$. vannamei and L. merguensis because it was able to inhibit the deterioration of shrimp quality for 5 days.

\section{Acknowledgement}

We thanks to Seto Windarto S.Pi., M.Sc., M.P as a companion lecturer for his suggestions, input, and guidance in this research activity.

\section{Authors' Contributions}

All authors discussed the results and contributed from the start to the final manuscript. Each author's contribution is as follows, FR and YY; was responsible for collected the data and drafting the manuscript. DS and AB; were responsible for the main conceptual ideas. SW; was responsible for revising the manuscript and AA; designed the figures and the table.

\section{Conflict of Interest}

All the authors of this research declare that they have no conflict of interest.

\section{Funding Information}

This research was partially funded by the Directorate General of Higher Education, Ministry of Education and Culture in Pendanaan PKM 2021.

\section{References}

Abdeltwab, W. M., Abdelaliem, Y. F., Metry, W. A., \& Eldeghedy, M. (2019). Antimicrobial effect of chitosan and nano-chitosan against some pathogens and spoilage microorganisms. Journal of Advanced Laboratory Research in Biology, 10(1):8-15.

Arsyi, N. Z., Nurjannah, E., Nurahlina, D., \& Budiyati, E. (2018). Karakterisasi nano kitosan dari cangkang kerang hijau dengan metode gelasi ionik. Jurnal Teknologi Bahan Alam, 2(2):106111.

Bajpai, V. K., Kamle, M., Shukla, S., Mahato, D. K., Chandra, P., Hwang, S. K., Kumar, P., Huh, Y. S., \& Han, Y. K. (2018). Prospects of using nanotechnology for food preservation, safety, and security. Journal of Food and Drug Analysis, 26(4):1201-1214.

Bambang, A. G., Fatimawali, dan Kojang, K. S. (2014). Analisis cemaran bakteri coliform dan identifikasi Escherichia coli pada air isi ulang dari depot di Kota Manado. Pharmacon, 3(3):325-334.

Bhattacharjee, B., Mishra, V. K., Rai, S. B., Parkash, O., \& Kumar, D. (2019). Structure of apatite nanoparticles derived from marine animal (crab) shells: An environment-friendly and 
cost-effective novel approach to recycle seafood waste. ACS Omega, 4(7):12753-12758.

Cahyaningsih, E., Megawati, F., \& Artini, N. P. E. (2021). Uji efektivitas ekstrak daun pare (Momordica charantia L.) sebagai bahan pengawet alami buah tomat. Jurnal Ilmiah Medicamento, $7(1): 41-46$.

Desvita, H., Faisal, M., Mahidin, \& Suhendrayatna. (2020). Preservation of meatballs with edible coating of chitosan dissolved in ricehull-based liquid smoke. 6(10):1-6.

Dwivedi, S., Prajpati, P., Vyas, N., Malviya, S., \& Kharia, A. (2017). A review on food preservation: methods, harmful effects and better alternatives. Asian Journal of Pharmacy and Pharmacology, 3(6):193-199.

Food and Agriculture Organization (FAO). (2020). The impact of COVID-19 on fisheries and aquaculture food systems possible responses.

Goy, R. C., Britto, D. D., \& Assis, O.B.G. (2009). A review of the antimicrobial activity of chitosan. Polímeros: Ciência e Tecnologia, 19(3):241247.

Guzman, M. G., Dille, J., \& Godet, S. (2012). Synthesis and antibacterial activity of silver nanoparticles against Gram-positive and Gram-negative bacteria. Nanomedicine: Nanotechnology, Biology, and Medicine, 8(1):37-45.

Hamdayanti, R. Yunita, N. N. Amin, \& T. A. Damayanti. (2012). Pemanfaatan Kitosan untuk Mengendalikan Antraknosa pada Pepaya (Colletotrichum gloeosporioides) dan Meningkatkan Daya Simpan Buah. Jurnal Fitopatologi Indonesia, 8(4): 97-102.

Krisnafi, Y., Yusrizal, Halim, S., Santoso, H., Suharto, Waluyo, A. S., Kusdinar, A., Danapraja, S., Pickassa, F. I., Alamsah, S., \& Fadly, Z. R. (2019). CPUE analysis of crab resources in Karangantu, Serang Banten, Indonesia. Bioflux, 12(2):610-617.

Lestari, S. D., Baehaki, A., \& Meliza, R. (2019). Aktivitas antibakteri kompleks kitosan-monosakarida terhadap patogen dalam surimi ikan gabus sebagai model matriks pangan. Jurnal Pengolahan Hasil Perikanan Indonesia, 22(1):80-88.
Li, B., Wu, X., Bao, B., Guo, R., \& Wu, W. (2021). Evaluation of $\alpha$-chitosan from crab shell and $\beta$-chitosan from squid gladius based on biochemistry performance. Applied Science, 11(7):1-19.

Lourenco, S. C., Martins, M. M., \& Alves, V. D. 2019. Antioxidants of natural plant origins: From sources to food industry applications. Molecules, 24(22):1-25.

Nguyen, V. B., Nguyen, D. N., Nguyen, A. D., Ngo, V. A., Ton, T. Q., Doan, C. T., Pham, T. P., Tran, T. P. H., \& Wang, S. (2020). Utilization of crab waste for cost-effective bioproduction of prodigiosin. Marine Drugs, 18(11):1-13.

Nurhayati, T., Abdullah, A. \& Sari, S. N. (2019). Penentuan formaldehid ikan beloso (Saurida tumbil) selama penyimpanan beku. Jurnal Pengolahan Hasil Perikanan Indonesia, 22(2):236-245.

Prasetiowati, A. L., Prasetya, A. T., \& Wardani, S. (2018). Sintesis nanopartikel perak dengan bioreduktor ekstrak daun belimbing wuluh (Averrhoa bilimbi L.) uji aktivitasnya sebagai antibakteri. Indonesian Journal of Chemical Science, 7(2):160-166.

Qonintannisa, S., Fadli, A., \& Sunarno, S. (2020). Sintesis nanokitosan dengan metode gelasi ionik menggunakan pelarut asam asetat dengan variasi konsentrasi kitosan. Jurnal Online Mahasiswa Fakultas Teknik, 7(2):1-4.

Ramezani, Zahra., M. Zarei., \& Raminnejad, N. (2015). Comparing the effectiveness of chitosan and nanochitosan coatings on the quality of refrigerated silver carp fillets. Food Control, (51):4348.

Sari, L. R., Sumpono, \& Elvinawati. (2019). Uji efektifitas asap cair cangkang buah karet (Hevea braziliensis) sebagai antibakteri Bacillus subtilis. Jurnal Pendidikan dan Ilmu Kimia, 3(1):34-40.

Sarwono, R. (2010). Pemanfaatan kitin/kitosan sebagai bahan anti mikroba. Jurnal Kimia Terapan Indonesia, 12(1):32-38.

Seabra, A. B., Haddad, P., \& Duran, N. (2013). Biogenic of nanostructural iron compounds application and perspektive. IET Nanobiotechnology, 7:9099.

See, A. S., Salleh, A. B., Bakar, F. A., \& Heng, N. 
A. (2010). Risk and health effect of boric acid. American Journal of Applied Sciences, 7(5):620-627.

Sumampoue, O. J. (2018). Uji sensitivitas antibiotik terhadap bakteri Escherichia coli penyebab diare balita di Kota Manado. Journal of Current Pharmaceutical Sciences, 2(1):104-110.

Supriyantini, E., Yulianto, B., Ridlo, A., Sedjati, S., \& Nainggolan, A. C. (2018). Pemanfaatan chitosan dari limbah cangkang rajungan (Portunus pelagicus) sebagai adsorben logam timbal $(\mathrm{Pb})$. Jurnal Kelautan Tropis, 21(1):23-28.

Syafitri, S., Metusalach, M., \& Fahrul, F. (2016). Studi kualitas ikan segar secara organoleptik yang dipasarkan di Kabupaten Jeneponto. Jurnal IPTEKS Pemanfaatan Sumberdaya Perikanan, 3(6):544-552.

Thulasiraman, V., M. S. Giri N., \& Anjineyulu K. (2021). Need for a balance between short food supply chains and integrated food processing sectors: COVID-19 takeaways from India. Journal of Food Science and Technology, 58(10):36673675.
Triastiningrum, C. D. \& Purnomo A. (2016). Perbandingan kemampuan kitosan dari limbah kulit udang dengan aluminium sulfat untuk menurunkan kekeruhan air dari outlet bak prasedimentasi IPAM Ngagel II. Jurnal Teknik ITS, 5(2):272278.

Utama, C., Nurwidiyanto, Baehaki, F., \& Ekawati, S. (2021). Analysis of formaldehyde content in salted fishat ciroyom market, Bandung. Journal of Sustainability Science and Technology, 1(1):35-43.

Vilar, J. J .C., Ribeaux, D. R., Alves da Silva, C. A., Campos-Takaki, D., \& Maria, G. (2016). Physicochemical and antibacterial properties of chitosan extracted from waste shrimp shells. International Journal of Microbiology, 1(1):1-7.

Xie, W., Zou, C., Tang, Z., Fu, H., Zhu, X., Kuang, J., \& Deng, Y. (2017). Well-crystallized borax prepared from boron-bearing tailings by sodium roasting and pressure leaching. $R S C$ Advances, 7(49):31042-31048. 